\title{
Using video-stimulated recall to understand teachers' perceptions of teaching and learning in the classroom setting
}

\section{Jelena Radišić ${ }^{1}$}

Department of Teacher Education and School Research, Faculty of Educational Sciences, University of Oslo

\author{
Aleksandar Baucal \\ Faculty of Philosophy, University of Belgrade
}

\begin{abstract}
This paper has emerged from a research project based on exploring the interplay between teachers' beliefs about teaching and learning and their registered practices in language and math classes at an upper secondary level. The text describes one aspect of the research project which involved developing a more in-depth understanding of teachers' beliefs about the teaching and the learning process in the classroom settings. The topic was explored through interviews with 13 teachers involved in this stage of the project. The interviews applied video stimulated recall with selected clips from the teachers' classrooms, and were analysed as part of the research. Data from the video stimulated interviews with the teachers were one of the essential components of the project allowing for the teachers' perspective to be heard and thus acknowledging them as important partners in the research. The paper reports findings from the interviews on how teachers interact with the videos and how their inputs have framed consequent stages of the analysis, in return shaping the researchers' understanding of particular classroom practices.
\end{abstract}

Keywords: video stimulated recall, teacher interviews, teacher reflection, classroom studies.

\section{Introduction}

The use of video is now well established as a tool in teacher education and classroom research, due to its exceptional characteristic to capture the richness and complexity of classrooms around the world (Goldman, Pea, Barron \&

1 jelena.radisic@ils.uio.no 
Derry, 2007; Stigler \& Hiebert, 1999). It offers researchers better insights into teachers' knowledge and their beliefs regarding teaching and learning (Clarke, Keitel \& Shimizu, 2006). Furthermore, it enables teachers to observe examples of effective practice by viewing videos from published resources (Hatch \& Grossman, 2009). As part of these practices video-stimulated recall (VSR further in the text) has also found its place in the process as a method to access participants' decisions during teaching (Powell, 2005).

Drawing on the data from a study exploring the interplay between teachers' beliefs about teaching and learning and their previously registered practices in language and math classes at an upper secondary level (Radišić \& Baucal, 2015), the authors focus on one aspect of the research project which involved the use of the VSR. The paper reports findings regarding specific uses of video-recordings. We focus, in particular, on how VSR supported teachers reflect on their own practice, and how the VSR has shaped researchers' understanding of teachers' beliefs of the teaching and learning process in the classroom setting.

\section{Theoretical framework}

Over the past 20 years video has become a widely used tool for examining classroom practice (Clarke et al., 2008). At the same time its use has spread to the areas of teacher education (Goldman et al., 2007; Masats \& Dooly, 2011), and in-service training (Borko, Jacobs, Eiteljorg, \& Pittmann, 2008; Brophy, 2004), allowing teachers to observe their own classrooms (Borko et al.,2008; Sherin \& van Es, 2009), their colleagues' lessons (Bliss \& Reynolds, 2004; Krajcik et al., 1996; Rosaen, Schram, \& Herbel-Eisenmann, 2002; Seago, 2004) or practices in countries different from their own (Hiebert et al., 2003) ${ }^{2}$.

In addition, various studies have demonstrated several benefits that the use of video brings to the process of learning and teaching (Goldman et al., 2007; van Es \& Sherin, 2008). Research shows that by watching videos from published resources (e.g. TIMSS video study) teachers gain opportunities to learn about effective practices (Hatch \& Grossman, 2009) and new instructional strategies (Sherin \& Han, 2004). The effects of watching classroom videos are also demonstrated in relation to teachers motivation, activation of prior knowledge (Lemke, 2007; Nind, Kilburn \& Wiles, 2015) and noticing areas of their own teaching about which they were previously unaware (Tripp \& Rich, 2012; Zhang, Lundeberg, Koehler \& Eberhard, 2011). In particular, it has been shown that when teachers observe their own video-recorded teaching, they tend to activate contextualized knowledge

2 The video material used for this purpose may substantially vary, from "edited" selected classroom sequences (van Es, 2009) to examples of good teaching of typical classroom lessons (Clarke et al., 2008). 
about their classroom and their teaching (Borko et al., 2008; Seidel, Stürmer, Blomberg, Kobarg, \& Schwindt, 2011). However, watching and reflecting on video recordings of teaching is not a simple process. Some authors stress that observing one's own video-recorded teaching requires more predetermination and scaffolding than observing videos of other teachers' practices (Kleinknecht \& Schneider, 2013). It also has been reported that teachers' participation in video supported dialogues is a skill that develops over time (van Es, 2009) and that especially preservice teachers, novice teachers or those with no prior experience in analysing videos tend not to gain insights and ideas simply by watching video-taped classroom situations (Calandra, Gurvitch\& Lund, 2008; Rosaen et al., 2002). Some researchers emphasize the importance of modelling such interactions (Santagata, 2009).

Structuring video sessions through dialogue or interviews has been labelled as a video-stimulated recall - VSR (Moyles, Adams, \& Musgrove, 2002; Powell. 2005). The term itself is used to represent a variety of techniques, usually involving the making of video recordings of particular observed practices. The gathered materials are then used to help participants (i.e. teachers) to recall their own thoughts at the time of observation (i.e. teaching), focusing on specific points of interest (Reitano \& Sim, 2010). VSR provides the teacher with time to reflect and revisit the recorded classroom scenes at any time and to repeatedly do so (Reitano, 2005). With each viewing session, participants (i.e. a teacher, a teacher and a researcher) can decide to focus on different aspects of the recorded event, while the dialogue in which they engage related to this event or situation may be more or less structured (i.e. through a prepared structured list of questions).

For Speer (2005) VSR interview is a research technique that closely relates data on beliefs and situated practices, with the potential to facilitate a mutual understanding of these beliefs and situated practices among teachers and researchers; additionally, it also serves to disclose teachers' beliefs as much more than a mere abstraction of their practices in the classroom. In fact, constructing shared understanding through the VSR, in return, shapes the construction and interpretation of data, enabling a deeper understanding of the whole process (Gellert, 2009), providing a direct link and dialogue between theory and practice (Reitamo \& Sim, 2010).This notion is in line with a wider discussion on teachers' knowledge (especially pedagogical content knowledge, Schulman, 1987), beliefs and practices and the question whether the former should be regarded as located somehow "in the head" of the individual teacher or whether these are all "social assets" (Depaepe, Verschaffel \& Kelchtermanns, 2013). The underlying paradigmatic differences impact the way in which knowledge, beliefs and practices are empirically investigated, which are either independent from the classroom context (i.e. 
questionnaires and scales) or within the enacted context (i.e. by classroom observations). Depaepe and colleagues (2013) conclude by calling for the integration of different theoretical perspectives and thus tools used for the research purposes, an affordance often embedded in the mixed method research designs (Creswell, 2008).

In earlier studies, Goldman and colleagues provide arguments (2007) for the inclusion of video-based research due to its power to deploy rhetoric to foster understanding of the nuances of social relationships and other situated parameters of human interactions. In addition, Fenstermacher (1994) discusses the difference between knowledge generated by researchers and the knowledge generated by practicing teachers.

Building on these premises, in our previous papers we have found out that math and Serbian language teachers in upper secondary schools in Serbia can be classified in four categories based on their professional beliefs (Radišić \& Baucal, 2015). Teachers' beliefs have been studied based on three scales which comprised the questionnaire (the Teacher beliefs scale, the Teachers' Sense of Efficacy Scale - Short Form (Tschannen-Moran, Woolfolk Hoy, 2001), and the List of Teachers' Practice).

The first group of teachers, "laissez-faire", perceived themselves as not highly effective in coping with disciplinary issues in the classroom ${ }^{3}$ and practices which stress their role in organizing the classroom routines or creating atmosphere conducive of learning. The group labelled "traditional stressing on atmosphere (further T/A)" reveals the opposite profile, scoring high on these practices. Their beliefs about teaching and learning, as in the former group, could be perceived as an eclectic mix of equally stressing both the roles of the students and the teachers in the knowledge construction. Teachers within this group perceived themselves to be the most competent within the domain of disciplinary issues. The "traditional group" reported the fewest use of practices focusing on students' active participation or creating atmosphere conducive of learning. Teachers' dominant role in the classroom and the one of "passing on the knowledge to students" is highlighted in their registered beliefs. Teachers labelled as the "modern group" scored highest on participatory and atmosphere conducive of learning practices, stressing the active role students have in the knowledge construction and viewing teaching as a process where knowledge is jointly co-constructed and shared between the teacher and the students. The analysis has also suggested that there is an association between teacher groups and the subject matter they teach. The language teachers were more distributed in the "laissez-faire" (35\%) and

3 During the VSR interviews all 4 styles were described to the teachers as part of the VSR scenario (see Appendix 1). Neither of the reported styles was perceived as negatively valued laden by the teachers themselves. None of the teachers knew to which teacher style they were categorized. 
"modern" labelled groups (51\%) while mathematics teachers mostly occupied "traditional" and "T/A" groups ( $82 \%$ against $4 \%$ within the "modern" group).

However, a purely quantitative study could not answer the question on how teachers' beliefs and their situated practices interact with one another. Thus, a video study and VSR supported our efforts in understanding that process, together with the teachers involved. Hence, in this paper we examine: (a) findings from teachers' interaction with the videos and the VSR interviews, and (b) how the use of the VSR has shaped the researchers' understanding of teachers' beliefs about the teaching and the learning process in the classroom settings. Through selected examples we will illustrate how gathered inputs framed consequent stages of the analysis, thus modelling researchers' views on how teacher beliefs and enacted practices are intertwined.

\section{Methods}

Sample. Data are drawn from the study involving 96 upper secondary teachers from grammar and vocational schools who teach Serbian language and literature (48 teachers) and Mathematics (48 teachers). All teachers were contacted through school principals and within school professional bodies, who gave an approval for conducting this study, leaving the final decision to the teachers' and students' voluntary participation. Teachers from 16 upper secondary schools in Belgrade took part in the study ${ }^{4}$.

Recordings. The qualitative data collection (video study and VSR interviews) was organized following and based on the results of the quantitative part of the study. Thirteen of the 96 teachers were sampled in the qualitative part of the study ( 10 women and 3 men). The thirteen teachers were selected as typical representatives of each of the four teacher groups based on distance of their individual profiles from the group centroids. This means that the discriminant analysis, which allows observation of the most prominent characteristics for each of the selected teacher groups, also allows researchers to choose typical representatives within each group (Field, 2013). The value of discriminant function for each of the 96 teachers was examined and the three teachers with highest probability (above 99\%) were chosen to be in the each of the selected groups ${ }^{5}$.

4 The sample comprised of $77 \%$ female and $23 \%$ male teachers; $12 \%$ of teachers were younger than $30 ; 38 \%$ were in their thirties, and $22 \%$ in their forties. $27 \%$ of teachers involved were over 50 years old.

5 In the "traditional" group, an additional teacher was filmed due to the initial inability of the originally drawn teacher to participate in filming (due to family illness). Not exceeding the planned time framework of the video study, this teacher was finally able to take part in the video study. Thus, 13 teachers were filmed - three in all the groups except the traditional one, where 4 teachers were filmed. 
Twenty-six lessons were filmed ( 2 for each teacher) using two cameras inside the classroom. While one camera followed the teacher, the other focused on the interaction between the students within the classroom ${ }^{6}$. All videotaping was done following regular teaching programme, allowing observation of typical teachers' practices and regular classroom activities the students were accustomed to.

Video stimulated recall interviews (VSR). A VSR interview was conducted with each of the filmed teachers in the period of two weeks after the final video-taping. All interviews lasted about one hour and were audiotaped, while the video prompts were shown on a laptop screen. The researcher also took field notes which served to capture nonverbal cues, any additional comments teacher may have had after the recording was stopped and any observed reactions with regard to the videos. Lesson sequences were balanced with respect to the teachers' subject matter, meaning all language teachers were prompted with similar types of situation from their lessons. The key elements of the VSR interviews included sections related to the beginning of the lesson, introduction of new concepts, and facilitating discussion and/ or problem solving process ${ }^{7}$. The scheme of the VSR interviews is given in Appendix $1^{8}$. All video clips, each between 3 and 4 minutes long, were edited as to allow teachers to simultaneously watch videos captured from both cameras ${ }^{9}$.

Data analysis. The data gathered from the VSR interviews were analysed using thematic analysis allowing the researchers to organize and describe the data in rich detail (Braun \& Clarke, 2006), particularly in respect to the sections of the VSR when teachers were exposed to video prompts (beginning of the lesson; introduction of new idioms; organizing a discussion in class and facilitating interpretations or working on a math problem). Initial analysis was continued by constant comparative analytic process (Merriam, 1998) to account for the different teacher types. All analyses also incorporated the field notes. Since one of the researchers was involved in the VSR process, the risk for euphemizing the effects of the VSR interviews was avoided by involving the other researcher into coding and analytical process (inter-rater agreement after initial coding was $85 \%$ ).

6 The researchers opted against the use of additional microphones and the third camera focusing on a selected pair of students due to the space constrictions in the classrooms of the participating schools.

7 This means that each selected episode was focused on a different aspect of the lesson.

8 As part of the study design teachers only interacted with the video during the VSR.

9 Software Premiere Pro was used to combine the two video sources (teacher and student cameras) into a single recording, using 'picture-in-picture' technique, merging also the audio captured in the two videos shots. 


\section{Results}

The results are divided in two sections. The first demonstrates how teachers interact with the videos and where particular differences or similarities have been observed among the teacher groups. In the second, the examples of perceived benefits in the use of the VSR for the overall research design are demonstrated.

\section{The camera in the classroom - 'Like having a mirror in front of me'}

The filmed teachers differed in respect to their professional experience in the classroom - the experience ranging from close to a decade to more than 30 years. In spite of all teachers reporting experience of having visitors in their classrooms throughout their careers (e.g. school psychologist, principals or pre-service teachers), they were never filmed and thus had never had experience with the video. This means that regardless of differences in the years of service and variances in the registered teachers beliefs and practices, all participating teachers had no opportunity to interact with the video, observing either themselves or other colleagues in that way.

All teachers in our study reported being aware of the camera as the first filming started, but very soon forgot all about it. Nevertheless, all were surprised that "students behaved as usual". One of the language teachers, belonging to the laissez-faire group, even commented how she talked to her students about it after the filming noticing that "they could have behaved slightly better than the usual".

Prior to the filming all teachers experienced some level of anxiety and preparatory steps were undertaken to minimize this. One of the researchers was present in the classroom prior to the actual filming announcing where the cameras would be positioned and what kind of equipment would be used. In this way the students and teachers could have a better perspective on how the process would unfold. Nonetheless, it seems that it was the actual filming that lowered the anxiety the most. All but one teacher (belonging to the traditional group) were very positive about the experience and ready to repeat the process if given the opportunity.

"I was a bit scared from it all. And probably in the beginning more, but when I recall of the whole lesson it just disappeared."

(Narrative 1; math teacher, belongs to modern group)

Interestingly, all teachers referred to video viewing and seeing oneself on it as 'having a mirror in front', yet a mixed stance was registered when teachers actually started interacting with the video during the VSR. Teachers belonging to "modern" and "laissez-faire" groups showed more initiative 
from the first moment they were exposed to the video, i.e. they would start commenting on the episode even before the researcher initiated a question, like in the example below when a teacher belonging to the modern group was shown a vignette from the beginning of her lesson.

"I am stunned of how slowly time passes. It seems this is taking too long. I mean I have already said what I will do in minute four, which basically is not much, but now I get the impression that literally as I come in, from the door, I should start talking, as it seems that a lot of time has been lost ... but it is only three minutes, three minutes is not that much, right?"

(Narrative 2, language teacher, after being shown a prompt from the introductory part of one of the filmed lessons, belongs to the modern group)

Throughout the VSRs, irrespective of their subject matter and years in service, the prevalent pattern with these two teacher groups (laissez-faire and modern) was taking imitative and commenting on the video-taped episodes of teaching. Teachers would not wait for the researcher to ask the question, but would rather reflect on the episode themselves ${ }^{10}$. The video actually served to activate their contextualized knowledge. However, the more traditional pattern of beliefs on teaching the teacher expressed, the more he/ she was prone to a structured talk and would rather wait for a question by the researcher to be raised in the situation of a joint viewing of the pre-prepared video vignettes.

The second observation we could make referred to teachers' capability not to merely react on the video, but also to use the video as a tool, which provided information on their practice. Similarly to the first finding, teachers belonging to the "laissez-faire" and "modern" groups were more focused on their own actions and how these actions shaped students' behaviour in return. Teachers in the "modern" group were also more proactive in defining the "problems" and seeking possible solutions that would change their own practice.

We give an example from the VSR episode with a language teacher belonging to the "laissez-faire" group (Excerpt 1). The teacher taught Serbian language and literature in a grammar school to second grade students. The topic of the video-taped class concerned the poem 'The Eagle'll by a Serbian poet Djura Jaksic. The teacher was shown an excerpt from the lesson in which she and the students discussed meaning of certain verses in the poem ${ }^{12}$.

10 The conclusion formulated based on the field notes taken after each VSR.

11 The original title in Serbian is 'Orao'.

12 The researcher did not comment on how the episode was previously coded. 
Excerpt 1: $\quad$ Transcript from the video prompt observed by the teacher

Teacher: $\quad$ reflective that's right ((writes down on the board, murmur))

(4.0) well now Ana since you were the first to notice this

(.) how did you come to the conclusion that this is a

symbolic, that is a reflective poem?

Ana: $\quad$ well because he doesn't really talk about the eagle (.) but he wants him through the poem

Teacher: all right

Ana: $\quad$ as symbolic to express his own contempt towards the world

Teacher: all right (.) all right, so you have noticed that the eagle

here is actually (.) a symbol of something right? that is a

substitute for whom?

(Turn omitted)

Teacher: $\quad$ you have recognized the poet himself in the eagle right?

Ana: $\quad{ }^{\circ}$ yes $^{\circ}$

Teacher: a:ll right (.) this is mostly correct, it can be the poet,

although it doesn't have to be just the poet

(Turn omitted)

Teacher: $\quad$ it can be any other=

Ana: $\quad=$ man who $=$

Teacher: $\quad=$ man who chooses himself for this way of life

Ana: $\quad{ }^{\circ}$ yes $^{\circ}$

In the given example, the teacher starts with an open question - "how did you come to the conclusion that this is a symbolic, that is a reflective poem?", addressing a specific student. As she continues, the questions become more directive, with teacher ending the exchange and providing the 'right' answer. Authors' perspective of the exchange was that it may be treated as an example of a situation in which the teacher, irrespective of actual intentions, has narrowed the learning space for the students. Open questions challenge students to reflect on different possibilities when formulating an answer, and they have to formulate it in a way for the answer to be clear to them, the teacher and the other students. When a question is closed, students are no longer compelled to clarify their own thinking and understanding of the discussed concepts. The teacher, watching her videotaped lesson came to a similar conclusion, stating "oh I didn't want to do that", continuing:

"I can see that I have concluded on some things instead of them, and they should have done it. I don't like it that it was me who concluded. I like it for them to do it or at least to try to suggest ... I can also see I am actually talking with only some students. I wasn't really successful in this lesson. I do try that we come together to a conclusion, but in this lesson it just didn't work."

(Narrative 3, Language teacher) 
The teacher further elaborated on her teaching philosophy and then returned again to the example above. However, the tone of her discourse never suggests that the reason she interacted with a small number of students was due to their lack of motivation, because they did not read the poem and/ or them lacking working routines. She rather questioned her own practice of engaging students. On the other hand, teachers from the two traditional groups, more often found the causes for poor outcomes of certain practices during the lesson related to the students' characteristics.

"Few students in the class can follow me, out of 28 in total ... in the last year about five are like when I mention something we get each other and they immediately know what we need to do. [...] you cannot expect and it is unreal actually it is if you have them from the first grade then they can do it all in your way..."

(Narrative 4, Math teacher, belonging to the traditional group)

In the above example, the teacher sees students' capacities or the lack of them as the major explanatory factor when it comes to the small percentage of the students who were able to follow the structure and the content of the lesson. Students are also seen as individuals who can be 'moulded' to solve problems in the most desired way. The knowledge comes from the outside space and is not created between the actors of the learning process.

\section{The use of VSR - benefits for the research design}

The main purpose of the VSR technique was to enter into a dialogue with teachers on particular practices captured in their lessons. The assumption was that, in this way, teachers can provide their unique 'insider' perspective, complementing the researchers' 'outsider' observations (Speer, 2005; Gellert, 2009). Excerpt \#1 can also serve as an example of this idea as it demonstrates how a particular teacher builds understanding of a lesson episode, providing the researcher with key elements that can be used in subsequent analysis. In addition, the VSRs also contributed shaping of the analysis that follows, in the light of teachers' registered practices, and previously captured beliefs. Please see a detailed example below.

As previously stated, the key elements of the VSR interviews included sections related to the beginning of the lesson, introduction of new concepts, and facilitating discussion and/or problem solving process. Our initial coding of all lessons was also based on that pattern and thus contributed to the selection of episodes for each of the VSRs. At the same time, each block of video recorded lesson episodes was also analysed from the perspective of the registered teacher groups (i.e. traditional, T/A, modern and laissez-faire) and subject matter (i.e. language and mathematics), focusing on particular 
moves both by the teachers and the students. In this way, we could check for similarities and differences at the level of subjects and teacher types.

The beginning of the lesson was among the lesson sections that we observed. Based on the captured lessons (video materials), we could observe that administrative activities such as roll calling and discussing with students the issues related to some scheduled activities like tests were put at the beginning. This part of the lesson was short, but fairly structured and was organized in the same manner for "traditional", "T/A" and "laissezfaire" teacher styles, irrespective of the subject they taught. Teachers also corroborated on it during their VSRs.

A less structured beginning was observed with the "modern" teacher group, that is, the beginning of the lesson for this group was coded as such. Descriptively, we can say we have observed that the teacher would enter the classroom, say a few brief sentences on the topic of the lesson and engage students in tasks. They could work in groups or individually, while the teachers would deal with administrative aspects of the lesson. If any of the students had questions (on and off topic), the teacher would answer them and continue with the administrative tasks. The beginning of the lesson seemed prolonged and intertwined with the subsequent parts of the lesson. The pattern was very much different from what we have observed for the other teacher types, and we attributed such pattern of activities possibly to teachers' fear that they would not have enough time during the lesson to complete all the activities they have planned. However, VSRs with the teachers offered a new insight. Here is how one of the math teachers described it:

"Giving them problems at the beginning of the lessons serves the purpose of getting them interested and immersed in the world of mathematics. Of course, there is always an element of repetition in it, but I never give them problems they cannot actually solve taking into account what they already know. Of course, we will clarify when it is necessary, but the lesson always begins with that."

(Narrative 5, Math teacher, belongs to modern type)

The same teacher told a story about how, when she had trained to be a teacher and later on, when she began teaching, she was told by the older colleagues to try to engage students as early as possible during the lesson. This advice seemed sound to her and corresponded with her initial idea how the teaching should unfold, so this is a practice she has used for over 30 years. A similar account was given by a language teacher from the same group. In her opinion "involving them [students] in the text as early as possible gives opportunities for deeper and more meaningful discussions. They are immersed much more quickly. Roll calling is something one can always do on the side." 
These reflections from the teachers contributed to our interpretation of the beginning of the lessons in these particular classrooms differently. We started viewing this beginning of the lesson as a part of the lesson structure that was planned and prepared and through which a clear concept of how teaching and learning should go about was actually enacted. Its seemingly "loose" structure that defies a more traditional pattern "teacher enters roll calling - teaching starts" was planned to enable the teachers to engage students into activities which provoke them to grapple with the material and get immersed into the topic. Every given task was there with the purpose to rely on students' previous knowledge and to use it in creating new ideas about literary works or understanding different paths leading to the correct solution of a particular math problem which would be discussed throughout the lesson.

These reflections from the teachers also contributed to changing our initial coding schemes related to the particular lesson segments. If we take the beginning of the lesson again our initial coding included observing whether any kind of warm up activities existed or not during the first 10 minutes, a simple yes or no code. However, this code was further developed to reflect not only whether a warm up activity existed or not, but also to reflect upon the nature of the warm up activity, and whether it provoked agency in students, which was then used in consecutive steps as the lesson progresses.

\section{Discussion}

In this article, we have examined findings regarding teachers' interaction with the video of their teaching practices and the VSR interviews demonstrating distinctive patterns of interaction among different groups of teachers. We also focused on how the VSR shaped the researchers' understanding of diverse teaching practices. All these inputs framed consequent stages of the analysis.

Regardless teachers had no prior experience with being video recorded or had opportunities to observe own recorded practice preceding their involvement in our study, most teachers reported that they would be willing to go through this process again and that their initial concerns diminished soon after the filming had taken place. This implies that both video and the VSR should be regarded as practices shaped by the teachers' prior experience and notions, and that these subsequently interfere with the extent of new and relevant knowledge that may emerge in the process of using the VSR (Tripp \& Rich, 2012; van Es, 2009).

Observing one's own teaching recorded in a video has been shown to activate contextualized knowledge (e.g. Narratives 2 and 3) about the observed teaching practices (Borko et al., 2008; Seidel et al., 2011), and overall 
understanding of the teaching and learning process (e.g. Narrative 4; Sherin \& van Es, 2009; van Es, 2009). Our study also corroborates these findings.

However, watching and reflecting on one's own video was a challenging process for some of the teachers in the study and these teachers needed more scaffolding than the others. This confirms previous findings on the importance of modelling such interactions (Santagata, 2009). Even though the teachers in our study had no prior experience with the use of video to record their own teaching, our study showed that teachers with different sets of beliefs about teaching interacted with the video differently, indicating that they may differ not only on the type of support they need, but also the types of VSR tools that may be used for these purposes.

As for the teachers' styles extracted in the overall study, we found that teachers belonging to two traditional groups struggled more with the videos. Teachers belonging to the other two groups expressed their own observations more readily even without the researcher prompting them for responses. This finding is particularly important since none of the teachers had prior chance to learn how to go about their own practice using video as a mirror to reflect on it. At the same time, our finding contradicts previous research results claiming that teachers with no prior experience in analysing the video tend not to gain insights and ideas from watching videotaped classroom situations (Calandra, Gurvitch \& Lund, 2008; Rosaen et al., 2002). We would rather argue that it is the nature of the teachers' core understanding of the process of learning that may make a crucial difference in ways that teachers use and/ or interact with video recordings of their practice. Watching a video of one's own practice demands a person to enter into a dialogue with another entity or oneself. In that process, an already established practice is reflected upon and new meanings may be constructed or an understanding of enacted practice may be rebuilt within the surrounding dialogical space. However, in order for this dialogue with oneself to take place, it seems that the teacher needs to approach learning as a social process mediated by existing cultural tools and practices and not as something which merely takes place within a particular individual (Säljö, 2009). We think that, in the latter case, the teachers needed not only to learn how to interact with the video and use opportunities from the VSRs, but that they also needed to reconstruct their own belief system regarding the ways in which learning takes place.

The second idea explored in this paper relates to the methodological affordances of VSR for the research design and research process. It is argued that VSR interview as a research technique enables researchers to closely relate to teachers' beliefs and practices, and potentially facilitate a mutual understanding among the teachers and the researchers, thus connecting theory and practice (Speer, 2005), and enabling deeper understanding of the process 
(Gellert, 2009), which without the VSR might have been misinterpreted in some of its parts. In this article such affordances were visible in several ways.

The quantitative part of the study enabled us to distinguish among different types of teachers and especially those who can be considered typical representatives in each of the selected groups. In that sense, the VSR has served as a validation of these findings as it helped us to corroborate the findings regarding the patterns observed in the video with the representatives of each group (e.g. Excerpt 1 - use of open questions during the lesson). We were also able to observe when a particular practice was not previously registered to be part of the teachers' belief system, and the VSR enabled us to discuss such practices with the teachers.

At the same time, the VSRs have mediated our understanding of the enacted practices and ways these practices are guided by the teachers' existing registered beliefs (e.g. differences in how a lesson begins between different teacher types). We argue that without being able to discuss specific practices with the participating teachers, our descriptions and conclusions would have been hampered and would not have fully portrayed the meaning behind particular actions.

Finally, the input given by the teachers taking part in the study enabled us to organize some of our analytical procedures differently as it forced us to look at the data again. Mainly, this meant organizing subsequent analysis through richer coding schemes (e.g. type of the warm-up activities in class) and constructing new ones. In this way VSRs have helped us to put in dialogue the quantitative and the qualitative data that were gathered in the study and to validate our findings from the quantitative part of the study to qualitative and vice versa. Thus, if we return to the still unanswered dilemma on teachers' knowledge, beliefs and practices and the question whether the former should be regarded as located somehow "in the head" of the individual teacher or whether these are all "social assets" (Depaepe, Verschaffel \& Kelchtermanns, 2013), we would argue the VSRs have facilitated the dialogue in between, offering an insight about both sides of the coin - knowledge and action, theory and practice.

\section{Limitations and future research}

Multiple data sources were used in this study, and all support the findings that there is interplay between teacher practices and their beliefs. VSR dialogues provided valuable information regarding the main focus of the study to the research team. However, some limitations also need to be taken into consideration. The study used only the teachers' own video recording as prompts. In addition, the teachers in our study had limited experience with the use of video recording for reflecting on their teaching, which to an extent may have influenced their 
readiness and ability to analyse the video prompts they watched. At the same time, some teachers did report on a sort of transformative effect the videos have had on them in observing their own teaching. The research team found such narratives more evident with the teachers belonging to the "modern" and "laissez faire" groups. In that respect, further, more systematic research is needed to explore how teachers interact with the video recordings of their practices in the light of their beliefs about teaching and learning process. It would be also necessary to explore whether some VSR prompts are more suitable than the others for different teacher groups (for instance, when they are watching their own video vs. examples of effective practices of other teachers). Such findings, in return, could facilitate existing practices of using video prompts in training pre-service and in-service teachers and the rather underdeveloped practice of using video prompts for training purposes in Serbia (Anđelković, 2015; Kovacs Cerović, Radišić \& Stanković, 2015).

\section{Literature}

Anđelković, A. (2015). Praktična znanja - nedostajuća karika u profesionalnom usavršavanju i radu nastavnika. Godišnjak Učiteljskog fakulteta u Vranju, 6, 127-139.

Bliss, T., \& Reynolds, A. (2004). Quality visions and focused imagination. In J. Brophy (Ed.), Using video in teacher education. Advances in research on teaching, Vol. 10 (pp. 29-53). Amsterdam: Elsevier.

Borko, H., Jacobs, J. K., Eiteljorg, E., \& Pittman, M. E. (2008).Video as a tool for fostering productive discussions in mathematics professional development. $\mathrm{Te}$ aching and Teacher Education, 24(2), 417-436.

Braun, V., \& Clarke, V. (2006). Using thematic analysis in psychology. Qualitative Research in Psychology, 3, 77-101.

Brophy, J. (2004). Using video in teacher education. Amsterdam, Netherlands: Elsevier.

Calandra, B., Gurvitch, R., \& Lund, J. (2008).An exploratory study of digital video editing as a tool for teacher preparation. Journal of Technology and Teacher Education, 16(2), 137-153.

Clarke, D. J., Mesiti, C., O’Keefe, C., Xu, L. H., Jablonka, E., Mok, I. A. C., et al. (2008). Addressing the challenge of legitimate international comparisons of classroom practice. International Journal of Educational Research, 46(5), 280-293.

Clarke, D., Keitel, C. Shimizu, Y. (Eds.) (2006). Mathematics Classrooms in 12 Countries: The Insider's Perspective (LPS Series Volume 1) Rotterdam: SENSE Publishers.

Creswell, J. (2008). Research Design: Qualitative, Quantitative, and Mixed Method Approaches. 3rd Edition, Thousand Oaks, CA: Sage.

Depaepe, F., Verschaffel, L. \& Kelchtermanns, G. (2013). Pedagogical content knowledge: A systematic review of the way in which the concept has pervaded mathematical educational research. Teaching and Teacher Education, 34, 12-25.

Fenstermacher, G. D. (1994). The knower and the known: The nature of knowledge in research on teaching. Review of Research in Education, 20, 3-56. 
Field, A. (2013). Discovering Statistics Using IBM SPSS Statistics. London, England: SAGE.

Gellert, U. (2009). Analysing accounts, discourse and mathematics classroom interaction: Reflections on qualitative methodology. In R. Kaasila (Ed.), Matematiik anjauonnontieteiden(pp. 9-34). Rovaniemi, Finland: Lapin yliopistopaino.

Goldman, R., Pea, R., Barron, B., \& Denny, S. J. (2007).Video research in the learning sciences. Mahwah, NJ: Lawrence Erlbaum.

Hatch, T., \& Grossman, P. (2009). Learning to look beyond the boundaries of representation: using technology to examine teaching. Journal of Teacher Education, 60(1), 70-85.

Hiebert, J., Gallimore, R., Garnier, H., Givven, K. B., Hollingsworth, H., Jacobs, J., Chui, A. M.-Y., Wearne, D., Smith, M., Manaster, A., Tseng, E., Etterbeek,W., Manaster, C., Gonzales, P. \& Stigler, J. W. (2003). Teaching mathematics in seven countries: Results from the TIMSS 1999 Video Study. Washington, DC: U.S. Department of Education.

Kleinknecht, M.\& Schneider, J. (2013). What do teachers think and feel when analyzing videos of themselves and other teachers teaching? Teaching and Teacher Education, 33 (July 2013), 13-23.

Kovacs Cerović, T., Radišić, J. \& Stanković, D.(2015). Bridging the Gap between Teachers 'Initial Education and Induction through Student Teachers' School Practice: Case Study of Serbia. Croatian Journal of Education, Vol.17; Sp.Ed.No.2 / 2015 43-70.

Krajcik, J., Soloway, E., Blumenfeld, P., Marx, R.W., Ladewski, B.L., \&Bos, N.D. (1996). The casebook of project practices: an example of an interactive multimedia system for professional development. Journal of Computers in Mathematics and Science Teaching, 15(1-2), 119-135.

Lemke, J. (2007). Video epistemology in- and outside the box: traversing attentional spaces. In R. Goldman, R. Pea, B. Barron, \& S. J. Derry (Eds.), Video research in the learning sciences (pp. 39-51). Mahwah, NJ: Lawrence Erlbaum.

Masats, D.\&Dooly, M. (2011).Rethinking the use of video in teacher education: A holistic approach. Teaching and Teacher Education 27(2011), 1151-1162.

Merriam, S.R. (1998). Qualitative Research and Case Study Applications in Education. San Francisco: Jossey Bass.

Moyles, J., Hargreaves, L., Merry, R., Paterson, F. \& Esarte-Sarries, V. (2003) Interactive teaching in the primary school: digging deeper into meanings. Buckingham: Open University Press.

Nind, M., Kilburn, D. \& Wiles, R. (2015). Using video and dialogue to generate pedagogic knowledge: teachers, learners and researchers reflecting together on the pedagogy of social research methods, International Journal of Social Research Methodology, DOI: http://dx.doi.org/10.1080/13645579.2015.1062628.

Powell, E. (2005). Conceptualising and facilitating active learning: Teachers' videostimulated reflective dialogues. Reflective Practice, 6(3), 407-418.

Radišić, J, \& Baucal, A. (2015). Portret nastavnika matematike u srednjoj školi: Kritička analiza dominantne prakse. Primenjena psihologija, 8(1), 25-46. 
Reitano, P. \& Sim, C. (2010).The value of video in professional development to promote teacher reflective practices. International Journal of Multiple Research Approaches, 4(3), 214-224.

Reitano, P. (2005). Using video stimulated recall and concept mapping in reflective teaching practices: Strengths, limitations and potential threats. In 33rd annual Australian teacher education association conference, Australia: Centre for Professional Development, Griffith University, Brisbane AU.

Rosaen, C., Schram, P., \& Herbel-Eisenmann, B. (2002). Using hypermedia technology to explore connections among mathematics, language, and literacy in teacher education. Contemporary Issues in Technology and Teacher Education, 2, 2-31.

Santagata, R. (2009). Designing video-based professional development for mathematics teachers in low-performing schools. Journal of Teacher Education, 60(1), 38-51.

Säljö, R. (2009). Learning, Theories of Learning, and Units of Analysis in Research, Educational Psychologist,44(3),202 -208.

Shulman, L. S. (1987). Knowledge and teaching: Foundations of the new reform. Harvard Educational Review, 57, 1-21.

Seago, N., Callahan, P., Driscoll, M., Jacobs, J., \&Nikula, J. (2012).Field guide to geometric transformations, congruence, and similarity. San Francisco: West Ed.

Seidel, T., Stürmer, K., Blomberg, G., Kobarg, M., \& Schwindt, K. (2011). Teacher learning from analysis of videotaped classroom situations. Does it make a difference whether teachers observe their own teaching or that of others? Teaching and Teacher Education, 27(2), 259-267.

Sherin, M. G., \& Han, S. Y. (2004).Teacher learning in the context of a video club. Teaching and Teacher Education, 20, 163-183.

Sherin, M. G., \& van Es, E. A. (2005).Using video to support teachers' ability to notice classroom interactions. Journal of Technology and Teacher Education, 13(3), 475-491.

Speer, N. M. (2005). Issues of methods and theory in the study of mathematics teachers' professed and attributed beliefs. Educational Studies in Mathematics, 58 (3), 361-391.

Stigler, J.W.\&Hiebert, J. (1999).The Teaching Gap. New York: The Free Press.

Tschannen-Moran, M., \&amp; Woolfolk Hoy, A. (2001). Teacher efficacy: Capturing an elusive construct. Teaching and Teacher Education, 17, 783-805.

Tripp, T.\& Rich, P. (2012).Using video to analyze one's own teaching. British Journal of Educational Technology, 43(4), 678-704.

van Es, E. A., \&Sherin, M. G. (2008).Mathematics teachers' "learning to notice" in the context of a video club. Teaching and teacher education, 24(2), 244-276.

van Es, E. (2009). Participants' roles in the context of a video club. Journal of the Learning Sciences, 18(1), 100-137.

Zhang, M., Lundeberg, M. A., Koehler, M. J., \& Eberhardt, J. (2011).Understanding affordances and challenges of three types of video for teacher professional development. Teaching and Teacher Education, 27(2), 454-462. 


\title{
Korišćenje video stimulisanog intervjua u razumevanju nastavničke percepcije nastave $i$ učenja
}

\section{Jelena Radišić}

Odeljenje za obrazovanje nastavnika i istrazivanja u školi, Fakultet obrazovnih nauka. Univerzitet u Oslu

\author{
Aleksandar Baucal \\ Filozofski fakultet, Univerzitet u Beogradu
}

Rad je nastao na osnovu istraživačkog projekta čiji je cilj bio da utvrdi uzajamno dejstvo između uverenja nastavnika o nastavi i učenju i njihovih praksi, zabeleženih na časovima jezika i matematike u višim razredima srednje škole. U tekstu se opisuje jedan aspekt istraživačkog projekta koji se odnosi na omogućavanje dubljeg razumevanja nastavničkih uverenja o procesu nastave i učenja u učionici. Tema je istraživana putem intervjua sa trinaest nastavnika koji su učestvovali $u$ ovoj fazi projekta. U intervjuima je korišćeno video stimulisano prisećanje pomoću odabranih video zapisa iz učionica ovih nastavnika, koji su analizirani kao deo istraživanja. Podaci iz video stimulirajućih intervjua predstavljali su jednu od najvažnijih komponenti u projektu i omogućili su da se čuje perspektiva nastavnika, kao i da se oni, na ovaj način, uvaže kao značajni partneri u istraživanju. U radu se izlažu nalazi izintervjua o tome kako su nastavnici reagovali na intervjue i kako su njihove reakcije oblikovale dalje faze analize, zauzvrat oblikujući i razumevanje određenih praksi u učionici od strane istraživača.

Ključne reči: video stimulisani intervju, intervjui sa nastavnicima, zapažanja nastavnika, istraživanje u učionici. 
Appendix 1.

General overview of the topics covered during the VSR interview (approx. length 60 minutes)

Introductory part

- recollection of the research process the teacher has participated in,

- discussion of general impressions of the research process,

- overview of the purpose of the VSR,

- exchange on the notion of teacher's every day practices and what it means for them to have a "good" or a "bad" day in class.

Main interview part with video prompts

- the teacher discusses general outcomes (s)he wishes to make during the lesson,

- following video prompts are introduced, thus allowing for facilitation of a discussion related to particular issues. These include beginning of the lesson, introduction of new idioms, organizing a discussion in class and facilitating interpretations and/or working on a math problem, classroom management, and repetitions. Type of prompts is unified as per teachers' subject matter, meaning all math teachers observe similar occasions from own lessons and language teachers similar type of situation from their own.

Final part

- discussion of the research results and teacher types. 